Pengaruh Gaya Mengajar Resiprokal Terhadap Hasil Belajar Smash Bola Voli

\title{
The Influence of Reciprocal Teaching Style on Volleyball Smash Learning Outcomes
}

\author{
Fajar Mugo Raharjo ${ }^{1}$, Agung Nugroho ${ }^{2}$, Ahmad Al Munawar ${ }^{3}$ \\ ${ }^{1,2,3}$ Sekolah Tinggi Olahraga dan Kesehatan Bina Guna \\ Jl. Alumunium Raya No 77 Tanjung Mulia, Medan, Indonesia \\ Email : *fajarraharjo86@gmail.com
}

\begin{abstract}
ABSTRAK
Penelitian ini bertujuan untuk mengetahui peningkatan hasil belajar Smash dalam permainan bola voli melalui gaya mengajar resiprokal pada siswa X SMA Swasta Perguruan Dharma Karya Tahun ajaran 2015/2016. Subjek dalam penelitian ini adalah kelas X dengan jumlah siswa sebanyak 32 orang siswa. Penelitian ini menggunakan metode Eksperimen, Setelah data terkumpul dan dilakukan analisis maka diperoleh hasil analisisnya : (1) dari data hasil tes belajar Pre test diperoleh 20 orang $(62,5 \%)$ yang telah mencapai tingkat ketuntasan belajar, sedangkan 12 orang $(37,5 \%)$ belum mencapai tingkat ketuntasan belajar. Dengan nilai rata-rata hasil belajar siswa adalah 64,4. (2) dari tes hasil belajar Pre testI diperoleh 28 orang $(87,5 \%)$ yang telah mencapai tingkat ketuntasan belajar, sedangkan 4 orang $(12,5 \%)$ belum mencapai tingkat ketuntasan belajar, dengan nilai rata-rata hasil belajar siswa adalah 78,1. Dalam hal ini dapat dilihat bahwa terjadi peningkatan nilai rata-rata hasil belajar siswa dari pre test ke pre testI yaitu peningkatan ketuntasan klasikalnya sebesar $25 \%$. Berdasarkan hasil analisis data dapat dikatakan bahwa melalui gaya mengajar resiprokal meningkatkan hasil belajar Smash dalam permainan bola voli pada siswa-siswi SMA Swasta Perguruan Dharma Karya Tahun ajaran 2015/2016.
\end{abstract}

\section{Kata kunci: Hasil Belajar Smash, Gaya mengajar Resiprokal}

\begin{abstract}
This study aims to determine the improvement of Smash learning outcomes in volleyball games through reciprocal teaching styles in X students of the Private High School of Dharma Karya in the 2015/2016 school year. The subjects in this study were class X with 32 students. This study uses the Experimental method, After the data is collected and analyzed, the results of the analysis are obtained: (1) from the data of the Pre-test learning results obtained 20 people $(62.5 \%)$ who have reached the level of mastery learning, while 12 people $(37.5 \%)$ has not reached the level of mastery learning. With an average value of student learning outcomes is 64.4. (2) 28 students $(87.5 \%)$ of the pre-test achievement test results have reached the level of mastery learning, while 4 people $(12.5 \%)$ have not reached the level of mastery learning, with an average value of student learning outcomes is 78,1 . In this case it can be seen that an increase in the average value of student learning outcomes from pre-test to pre-testI is an increase in classical completeness by $25 \%$. Based on the results of data analysis, it can be said that through reciprocal teaching styles increases the learning outcomes of Smash in volleyball games for students of the Private High School of Dharma Karya in the 2015/2016 school year.
\end{abstract}

Keywords: Smash Learning Outcomes, Reciprocal teaching style 


\section{PENDAHULUAN}

Dalam dunia kehidupan, pendidikan memegang peranan penting karena pendidikan merupakan wahana untuk meningkatkan dan mengembangkan kualitas sumber daya manusia (Lubis, A. E., \& Agung Nugroho, 2020), (Keliat, P, 2020), (Karo-Karo, at all, 2020).. Sejalan perkembangan dunia pendidikan yang semakin pesat menuntut lembaga pendidikan untuk dapat menyesuaikan dengan perkembangan ilmu pengetahuan. banyak perhatian khusus diarahkan kepada perkembangan dan kemajuan pendidikan guna meningkatkan mutu dan kualitas pendidikan (Catur Winata, D., 2019). Salah satu cara yang dilakukan untuk meningkatkan kualitas pendidikan adalah dengan pembaharuan sistem belajar yang kurang baik.

Proses belajar mengajar merupakan suatu aktivitas yang bertujuan untuk mengarahkan peserta didik pada perubahan tingkah laku yang diinginkan. Peningkatan mutu pembelajaran tentunya dapat kita lihat dari bagaiman cara guru dalam membawakan pembelajaran pada peserta didiknya. Hal tersebut bisa di pahami karena mengarahkan peserta didik menuju perubahan yang diinginkan merupakan suatu pekerjaan yang berat. Sekolah sebagai tempat atau wadah pendidikan formal yang mempunyai tugas untuk menyelenggarakan pembinaan mentalspritual, intelektual, dan khususnya pembinaan kualitas fisik peserta didik melalui mata pelajaran pendidikan jasmani.

Seiring dengan uraian diatas, penggunaan gaya mengajar dalam kegiatan proses belajar mengajar merupakan salah satu cara pendekatan yang dilakukan untuk bisa kemudian diharapkan meningkatkan hasil belajar peserta didik.

Dalam hal ini, metode mengajar dalam pemberian latihan maupun proses pelaksanaan pembelajaran sangat perlu diperhatikan. Kegagalan dari usaha pencapaian tujuan yang diharapkan bisa saja terjadi karena metode yang digunakan guru dalam menyampaikan pembelajaran tidak memberikan kesempatan kepada siswa untuk melakukan gerakan dengan leluasa.

Penyelenggaraan pendidikan jasmani di sekolah selama ini berorientasi pada suatu titik pusat yaitu guru. Kenyataan ini dapat dilihat melalui pengamatan yang dilakukan penulis di lapangan bahwa gurulah yang memiliki kuasa penuh dalam proses belajar mengajar tanpa mempertimbangkan aspek perkembangan motorik peserta didik. Sehingga metode yang diajarkan tidak berjalan dengan baik. Dalam mencapai tujuan pembelajaran, diharapkan tentunya sebagai seorang guru harus mengusai metode pembelajaran. Karena apabila ingin mencapai hasil pembelajaran yang baik, sebagai seorang guru harus memiliki kemampuan akademik yang lebih baik dalam membawakan matapelajarannya terkhusus pendidikan jasmani. Sejalan dengan itu, penggunaan metode mengajar sebagai alat bantu pelaksanaan mengajar merupakan salah satu bentuk pendekatan yang bisa diharapkan dalam meningkatkan hasil belajar .

Penggunaan gaya mengajar itu sendiri bukanlah suatu hal yang baru dalam dunia pendidikan. Pada umumnya guru sudah menerapkan di sekolah. Hanya saja, untuk pendidikan jasmani gaya yang cenderung digunakan adalah gaya komando.

Banyak metode atau gaya mengajar yang dapat digunakan dalam pembelajaran penjas. Metode yang digunakan sebaiknya disesuaikan dengan materi pelajaran yang akan disampaikan. Beberapa metode mengajar dapat diterapkan selama pembelajaran berlangsung tergantung dari keadaan kelas atau siswa. 
Permainan bola voli merupakan satu bentuk olahraga permainan yang ada dalam kurikulum pendidikan pendidikan jasmani sekolah. Menurut Ahmadi (2007:20) teknik dasar permainan bola voli yaitu teknik passing atas, servis, passing bawah, smash, blocking.

Hasil observasi yang dilakukan peneliti di sekolah SMA Swasta Perguruan Dharma Karya pada bulan maret pemahaman dan kemampuan dalam permainan bola voli para peserta didik di sekolah masih kurang menguasai, khususnya kemampuan dasar untuk melakukan smash kurang menguasai teknik tersebut. Pada saat siswa melakukan smash mereka tidak memakai awalan dengan melangkahkan kaki serta mengayunkan kedua tangan tetapi langsung melompat sehingga timing bola dengan lompatan tidak seirama. Hal ini merupakan hal yang sangat sulit dilakukan siswa karena mereka belum dapat mengatur kapan dan dimana mereka harus melompat sehingga posisi tubuh mereka berada tepat di belakang bola dan memukul bola tepat di depan atas kepala melainkan mereka memukul bola ketika bola berada tepat di atas kepala sehingga mereka tidak bisa melihat bola dan melihat arah bola yang di tuju pada saat bersamaan. Hal seperti di atas juga bisa di karenakan mereka melompat terlalu dekat dengan net yang membuat mereka berada di bawah bola dan pada waktu mendarat, tangan yang di gunakan untuk memukul bola akan menyentuh net. Pada intinya para siswa sangat kesulitan dan belum dapat melaksanakan gerakan smash dalam permainan bola voli dengan teknik yang benar (Nuril, 2007).

Sedangkan menurut Hamalik (2001:27) belajar adalah "modifikasi atau memperteguh kelakuan melalui pengalaman". Menurut pengertian ini, belajar merupakan suatu proses, sustu kegiatan dan bukan suatu hasil atau tujuan.
Belajar bukan hanya mengingat, akan tetapi lebih luas dari itu yakni mengalami, memang jika dilihat sangat banyak ahliahli yang telah mencoba menfasirkan arti dari belajar.

\section{METODE}

Penelitian ini dilaksanakan di lapangan Voli Sekolah SMA Swasta Perguruan Dharma Karya Tahun Ajaran 2015/ 2016". Penelitian ini dilakukan dalam dua fase, dimana setiap fase berisikan tindakan berupa pelaksanaan pembelajaran dengan gaya mengajar Resiprokal yang disesuaikan dengan materi pelajaran. Sebelum pelaksanaan Tindakan I dilakukan, peneliti terlebih dahulu melakukan tes awal untuk melihat sejauh mana pemahaman siswa akan smash bola voli. Hal ini diperlukan sebagai informasi awal bagi peneliti untuk dapat memberikan pemecahan masalah dan kendala yang dihadapi siswa dalam smash bola voli pada pelajaran penjaskes.

\section{HASIL DAN PEMBAHASAN}

Adapun deskripsi hasil data awal yang diproleh siswa dapat di lihat pada tabel berikut ini:

Tabel 1. Deskripsi data awal Smash Siswa

\begin{tabular}{ccccc}
\hline No & $\begin{array}{c}\text { Hasil } \\
\text { Tes }\end{array}$ & $\begin{array}{c}\text { Jumlah } \\
\text { Siswa }\end{array}$ & Persentase & $\begin{array}{c}\text { Ketera } \\
\text { ngan }\end{array}$ \\
\hline 1. & Skor & 27 & $84,37 \%$ & Tidak \\
& & & & Tuntas \\
& $<64$ & & & \\
\hline 2. & Skor & 5 & $15,63 \%$ & Tuntas \\
& & & & \\
& $>65$ & & &
\end{tabular}

Berdasarkan tabel deskripsi hasil tes awal smash di atas dapat dilihat bahwa hasil be lajar siswa dalam pembelajaran 
smash masih rendah. Dari 32 orang siswa yang benjadi subjek dalam penelitian ini, ternyata hanya 5 orang siswa $(15,63 \%)$ yang sudah memiliki ketuntasan belajar, sedangakan selebihnya yaitu 27 orang siswa $(84,37 \%)$ belum memiliki ketuntasan belajar. Nilai rata - rata yang diproleh hanya mencapai 50.Pre test Berdasarkan hasil yang dicapai dalam proses pembelajaran dengan menggunakan gaya mengajar Resiprokal pada kelas $\mathrm{X}$ SMA Swasta Perguruan Dharma Karya permasalahan yang dialami siswa dalam mempelajari materi smash bola voli adalah siswa kurang bersemangat, siswa kurang mengerti pada saat melakukan sikap memainkan bola dalam smash bola voli, dan siswa terlihat canggung dengan gaya mengajar yang dipakai dalam pembelajaran.

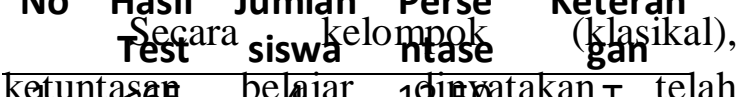
tercapai jika sekurang-\%kurangnyata85\% d2ri sis 65 yang ada 87t,slam Tutetempok bersangkutan telah memenuhi kriteria ketuntasan minimal per individu sebesar $\geq$ 65\%.( Berdasarkan Kurikulum Sekolah).

Tabel 2.Deskripsi hasil belajar pre test

\begin{tabular}{ccccc}
\hline $\begin{array}{c}\text { No } \\
\end{array}$ & $\begin{array}{l}\text { Hasil } \\
\text { Tes }\end{array}$ & $\begin{array}{l}\text { humla } \\
\text { e }\end{array}$ & $\begin{array}{l}\text { Persentas } \\
\text { e }\end{array}$ & $\begin{array}{l}\text { Ketranga } \\
\text { n }\end{array}$ \\
\hline 1. & $\geq 65$ & 17 & $53,13 \%$ & Tidak \\
& & & & tuntas \\
\hline 2. & $\leq 65$ & 15 & $46,87 \%$ & Tuntas \\
\hline
\end{tabular}

Adapun kesulitan-kesulitan yang dialami siswa dalam pembelajaran dengan menggunakan gaya mengajar resiprokal antara lain adalah: a) Siswa kurang baik melakukan gerakan teknik smash dalam permainan bola voli. Untuk mengatasinya guru mengevaluasi kesalahan siswa dalam melakukan gerakan dan memberikan motivasi kepada siswa, b) Siswa masih terlihat canggung dengan gaya mengajar resiprokal yang dipakai dalam pembelajaran. Untuk mengatasi guru menjelaskan gaya resiprokal dan tujuan pembelajaran (Syaleh, M., 2019), (Siswanto, Tedi Purbangkara, 2019), (Shandy Rizaldi, Rahmah Rahmah, I Wayan Sukrawan, 2019).

Setelah proses observasi dilakukan, selanjutnya dilakukan kembali analisis dari data post test yang ditetapkan. Dari hasil belajar pre test yang didapat kemudian kembali reduksi dan dipaparkan bentuk tabel dengan menggunakan rumus yang sama seperti pre test.

Tabel 3. Deskripsi Hasil Belajar Post test

\section{KESIMPULAN}

Berdasarkan hasil analisis data dan pembahasan, maka hasil penelitian dapat disimpulkan sebagai berikut: Penerapan gaya mengajar dalam pembelajaran smash bola voli dapat dijadikan alternative untuk meningkatkan kemampuan Hasil Belajar smash bola voli bagi siswa kelas X SMA Swasta Perguruan Dharma Karya yang dibuktikan dengan rendahnya nilai ratarata awal siswa sebesar 8,0 (50\%) namun setelah dilakukan pre test di dapat rata-rata sebesar 10,21 (63,8\%) dan rata-rata menjadi meningkat sebesar $12,5(78,1 \%)$ setelah dilakukan pre testI.

\section{DAFTAR PUSTAKA}

Catur Winata, D. (2019). Pengaruh Gaya Mengajar Dan Motivasi Belajar Terhadap Hasil Belajar Passing Atas Dalam Bola Voli Pada Siswa Kelas VII Smp Swasta Amal Bakti 
Medan Tahun Ajaran 2019/2020. Jurnal Ilmiah STOK Bina Guna Medan, 1(1), 8-16. Retrieved from https://jurnal.stokbinaguna.ac.id/ind ex.php/JSBG/article/view/7.

Hamalik, Oemar. (2001). Proses Belajar Mengajar. Jakarta: Bumi Aksara.

Keliat, P. (2020). Application Of Learning Variations To Improve The Learning Outcomes Of The Forehand Drive Table Tennis Game In Class Students Viii Junior High School Muhammadiyah 3 Medan Academic Year 2018/2019. Jurnal Ilmiah STOK Bina Guna Medan, 2(1), 13-18. Retrieved from https://jurnal.stokbinaguna.ac.id/ind ex.php/JSBG/article/view/88

Karo-Karo, A. A. P., Khairul Usman, Liliana Puspa Sari, Ratna Dewi, \& Simangunsong, B. A. (2020). Result Of The Formation Of Student Characters In Full Day School. Jurnal Ilmiah STOK Bina Guna Medan, 2(1), 43-50. Retrieved from https://jurnal.stokbinaguna.ac.id/ind ex.php/JSBG/article/view/98

Lubis, A. E., \& Agung Nugroho. (2020). Improving Learning Outcomes Of Shooting Soccer With Audio Visual Media In Class V Students Of Sd Titi Berdikari Medan. Jurnal Ilmiah STOK Bina Guna Medan, 2(1), 1-6. Retrieved from https://jurnal.stokbinaguna.ac.id/ind ex.php/JSBG/article/view/86

Nuril. (2007). Panduan Olah Raga Bola Voli. Surakarta, Era Pustaka Utama.

Shandy Rizaldi, Rahmah Rahmah, I Wayan Sukrawan. (2019). Minat Guru Pendidikan Jasmani Sekolah Dasar Untuk Berwirausaha Dalam Bidang Olaharaga Di Kecamatan Baolan. Tadulako Journal Sport Sciences And Physical Education, 7(2). 101113.
Siswanto Siswanto, Tedi Purbangkara. (2019). Persepsi Siswa Terhadap Model Pembelajaran Resiprokal pada Pembelajaran Servis Bawah Bola Voli di SMPN 1 Tirtajaya. Jurnal Speed (Sport, Physical, Empowerment), 2(2), 49-56. 10.35706/speed.v2i2.3379.

Syaleh, M. (2019). Penerapan Gaya Mengajar Resiprokal Untuk Meningkatkan Hasil Belajar Renang Gaya Bebas Pada Mahasiswa Sekolah Tinggi Olahraga Dan Kesehatan (Stok) Bina Guna. Jurnal Ilmiah STOK Bina Guna Medan, 1(1), 30-39. Retrieved from https://jurnal.stokbinaguna.ac.id/ind ex.php/JSBG/article/view/11. 